\title{
Reflections of Practical Implementation of the Academic Course Analysis and Design of Algorithms Taught in the Universities of Pakistan \\ Faryal Shamsi ${ }^{1}$, Muhammad Irshad Nazeer ${ }^{1}$, Raheel Ahmed Memon ${ }^{1}$
}

\begin{abstract}
The Analysis and Design of Algorithm is considered as a compulsory course in the field of Computer Science. It increases the logical and problem-solving skills of the students and make their solutions efficient in terms of time and space. These objectives can only be achieved if a student practically implements what he or she has studied throughout the course. But if the contents of this course are merely studied and rarely practiced, the actual goals of the course are not fulfilled. This article will explore the extent of practical implementation of the course of analysis and design of algorithm. Problems faced by the computer science community and major barriers in the field are also enumerated. Finally, some recommendations are made to overcome the obstacles in the practical implementation of analysis and design of algorithms.
\end{abstract}

Keywords: Analysis and Design of Algorithms, Teaching and Practice, Analysis in Pakistan.

\section{Introduction}

The core objective of this course is to introduce the tools and techniques for the problem solving and decision-making skills of a programmer. The question is, whether the objectives are practically achieved? How many people implement what is actually learned in the course? To answer these questions in appropriate way, a research was conducted. The contents of the research will be explored in further subsections.

- Analysis and Design of Algorithms Algorithms are the basis for the solution of computational problems and identification of computational complexities [2]. The algorithm is defined [1] as the formal sequence of steps which converts an input into the output. We can say that the [2] analysis of algorithm is to evaluate the effectiveness of the algorithm and number of resources required to use implement it.

\section{- Core objectives of the field}

The field targets to reduce the overall cost of solving a problem, the cost both in terms of time and money. The course of Analysis and design of algorithms has the following objectives -

- Estimates the running time of the algorithm

- Estimates the storage space or memory capacity required

- Reduces the number of resources required

- Identifies different methods of solving the same problem

- Determines the best solution for a computational problem

- Why we analyse the algorithm today?

With the advent of technology we have enough computational power and storage not only available but wasted in most of the cases. In such environment where abundant computational resources are available, one can take the importance of analysis and design of algorithm for granted.

The literature [1] suggests that even if we consider that we have infinite resources available, which is not actually the case.

${ }^{1}$ Department of Computer Science, Sukkur IBA University, Sukkur, Sindh, Pakistan Corresponding email: faryal.mscs16@iba-suk.edu.pk 
Even then, we need to study this course and understand the importance of analysis of algorithms. The resources may be infinite but will never be free [1]. So, we still need to analyze to the algorithms to -

- Identify the solution that generates the required output.

- Look for the easiest solution and implement it

- Ensure to comply with the software engineering standards.

- Teaching Methodology for Analysis and Design of Algorithms

Conventional teaching methodology was questioned in the research conducted by Xuemin Zhang in 2014 [3]. Some teaching reforms are suggested in literature to decrease the difficulty and increase the motivation of students [3]. A research based teaching methodology should be followed which can facilitate the learning environment by incorporating theory and practical. Combination of blackboard and multimedia is also prescribed by the study [3]. The course content comprises one-way communication most of the time and students are not able to interact and contribute in the classroom. According to Zhang the multimedia support encourages student to be creative and innovative [3].margin in this template measures proportionately more than is customary. This measurement and others are deliberate, using specifications that anticipate your paper as one part of the entire proceedings, and not as an independent document. Please do not revise any of the current designations.

\section{Methodology}

This research is based on an online survey where 200 respondents with the background of computer science participated. 10 experts of the field were also interviewed. Some focused group discussion sessions were also conducted with some students of the course. The whole community of computer science could not be reached with the limited time and budget. So, conveniently stratified sampling was done to divide the population in three strata -

- Students

- Teachers

- Professionals

The practical implementation of analysis of algorithm and its barriers cannot be quantified. For this purpose a scaling instrument was developed for quantification. To measure the extent of practical implementation of the course consensus based factor scaling was used. For making consensus a penal of ten experts of the field was developed.

\section{- $\quad$ Factors to be demonstarted}

Following factors were suggested by the experts, to be demonstrated, in regard to the practical implementation of analysis and design o algorithm -

- Resource Management (CPU, RAM and so on.)

- Attempting various techniques

- Code Optimization

- Improved Problem Solving

- Improved Decision Making

\section{- Major Distractors}

To measure the major distraction from the analysis, following factors were suggested be analyzed, by the expert panel-

- Mathematical Background

- Personal Interest

- Ability to relate with expressions with the realworld problems

- Teaching Methodology

\section{Results}

200 respondents took part in an online survey. One hundred respondents were the students of 2 reputable institutes of Sukkur city. Forty were the teachers of same institutes. And 60 were the computer science professionals from the various organizations of Pakistan. The questionnaire was designed using the semantic differential factors scaling 
Faryal Shamsi (et al.) Practical Implementation of academic course Analysis and Design of Algorithms taught in the Universities Of Pakistan

technique. The factors of practical implementation of the course of analysis and design of algorithm were identified by consensus of a panel of 10 experts of the field. The questions, responses from Teachers, Students and Professionals are indicated in Table 1,2 and 3 respectively.

TABLE I. Feedback from 40 Teachers

\begin{tabular}{|c|c|c|c|}
\hline \multirow{2}{*}{$\begin{array}{l}\text { S. } \\
\text { no }\end{array}$} & \multicolumn{3}{|c|}{ Questions and Responses } \\
\hline & Question Contents & YES & NO \\
\hline 1 & $\begin{array}{l}\text { Do you check the } \\
\text { available resources of } \\
\text { the system such as } \\
\text { speed of the processor } \\
\text { or capacity of RAM } \\
\text { before programing? }\end{array}$ & 30 & 10 \\
\hline 2 & $\begin{array}{l}\text { After solving a } \\
\text { problem, do you try it } \\
\text { again to find a better } \\
\text { solution? }\end{array}$ & 15 & 25 \\
\hline 3 & $\begin{array}{l}\text { Do you think that the } \\
\text { course of analysis \& } \\
\text { design of algorithm } \\
\text { has improved your } \\
\text { decision -making } \\
\text { skills? }\end{array}$ & 40 & 0 \\
\hline 4 & $\begin{array}{l}\text { Do you think that the } \\
\text { course of analysis \& } \\
\text { design of algorithm } \\
\text { has improved your } \\
\text { problem solving } \\
\text { skills? }\end{array}$ & 32 & 8 \\
\hline 5 & $\begin{array}{l}\text { Do you find the course } \\
\text { of analysis and design } \\
\text { of algorithms } \\
\text { interesting? }\end{array}$ & 27 & 13 \\
\hline 6 & $\begin{array}{l}\text { Do you have weak } \\
\text { mathematical } \\
\text { foundation? }\end{array}$ & 33 & 7 \\
\hline 7 & $\begin{array}{l}\text { Do you find it difficult } \\
\text { to relate the real world } \\
\text { problems with } \\
\text { mathematical } \\
\text { expressions? }\end{array}$ & 9 & 31 \\
\hline 8 & $\begin{array}{l}\text { Are you satisfied with } \\
\text { the teaching } \\
\text { methodology followed }\end{array}$ & 35 & 5 \\
\hline
\end{tabular}

\begin{tabular}{|c|c|c|c|}
\hline S. & Questions and Res & onses & \\
\hline no & Question Contents & YES & NO \\
\hline & $\begin{array}{l}\text { for the analysis \& } \\
\text { design of algorithms? }\end{array}$ & & \\
\hline
\end{tabular}

TABLE II. Feedback from 100 Students

\begin{tabular}{|c|c|c|c|}
\hline \multirow{2}{*}{$\begin{array}{l}\text { S. } \\
\text { no }\end{array}$} & \multicolumn{3}{|c|}{ Questions and Responses } \\
\hline & Question Contents & YES & NO \\
\hline 1 & $\begin{array}{l}\text { Do you check the } \\
\text { available resources of } \\
\text { the system such as } \\
\text { speed of the processor } \\
\text { or capacity of RAM } \\
\text { before programing? }\end{array}$ & 8 & 92 \\
\hline 2 & $\begin{array}{l}\text { After solving a } \\
\text { problem, do you try it } \\
\text { again to find a better } \\
\text { solution? }\end{array}$ & 14 & 86 \\
\hline 3 & $\begin{array}{l}\text { Do you think that the } \\
\text { course of analysis \& } \\
\text { design of algorithm } \\
\text { has improved your } \\
\text { decision making } \\
\text { skills? }\end{array}$ & 37 & 63 \\
\hline 4 & $\begin{array}{l}\text { Do you think that the } \\
\text { course of analysis \& } \\
\text { design of algorithm } \\
\text { has improved your } \\
\text { problem solving } \\
\text { skills? }\end{array}$ & 56 & 44 \\
\hline 5 & $\begin{array}{l}\text { Do you find the course } \\
\text { of analysis and design } \\
\text { of algorithms } \\
\text { interesting? }\end{array}$ & 76 & 24 \\
\hline 6 & $\begin{array}{l}\text { Do you have weak } \\
\text { mathematical } \\
\text { foundation? }\end{array}$ & 12 & 88 \\
\hline 7 & $\begin{array}{l}\text { Do you find it difficult } \\
\text { to relate the real world } \\
\text { problems with } \\
\text { mathematical } \\
\text { expressions? }\end{array}$ & 78 & 22 \\
\hline 8 & $\begin{array}{l}\text { Are you satisfied with } \\
\text { the teaching } \\
\text { methodology followed } \\
\text { for the analysis \& } \\
\text { design of algorithms? }\end{array}$ & 90 & 10 \\
\hline
\end{tabular}

Sukkur IBA Journal of Computing and Mathematical Sciences - SJCMS | Volume 1 No. 2 July - December 2017 @ Sukkur IBA University 
Faryal Shamsi (et al.) Practical Implementation of academic course Analysis and Design of Algorithms taught in the

TABLE III. Feedback from 60 Professionals

\begin{tabular}{|c|c|c|c|}
\hline \multirow{2}{*}{$\begin{array}{l}\text { S. } \\
\text { no }\end{array}$} & \multicolumn{3}{|c|}{ Questions and Responses } \\
\hline & Question Contents & YES & NO \\
\hline 1 & $\begin{array}{l}\text { Do you check the } \\
\text { available resources of } \\
\text { the system such as } \\
\text { speed of the processor } \\
\text { or capacity of RAM } \\
\text { before programing? }\end{array}$ & 11 & 39 \\
\hline 2 & $\begin{array}{l}\text { After solving a } \\
\text { problem, do you try it } \\
\text { again to find a better } \\
\text { solution? }\end{array}$ & 23 & 27 \\
\hline 3 & $\begin{array}{l}\text { Do you think that the } \\
\text { course of analysis \& } \\
\text { design of algorithm } \\
\text { has improved your } \\
\text { decision making } \\
\text { skills? }\end{array}$ & 35 & 25 \\
\hline 4 & $\begin{array}{l}\text { Do you think that the } \\
\text { course of analysis \& } \\
\text { design of algorithm } \\
\text { has improved your } \\
\text { problem solving } \\
\text { skills? }\end{array}$ & 21 & 39 \\
\hline 5 & $\begin{array}{l}\text { Do you find the course } \\
\text { of analysis and design } \\
\text { of algorithms } \\
\text { interesting? }\end{array}$ & 41 & 19 \\
\hline 6 & $\begin{array}{l}\text { Do you have weak } \\
\text { mathematical } \\
\text { foundation? }\end{array}$ & 36 & 24 \\
\hline 7 & $\begin{array}{l}\text { Do you find it difficult } \\
\text { to relate the real world } \\
\text { problems with } \\
\text { mathematical } \\
\text { expressions? }\end{array}$ & 10 & 50 \\
\hline 8 & $\begin{array}{l}\text { Are you satisfied with } \\
\text { the teaching } \\
\text { methodology followed } \\
\text { for the analysis \& } \\
\text { design of algorithms? }\end{array}$ & 33 & 27 \\
\hline
\end{tabular}

To understand the trends of the feedback from the teachers, students and professionals, the responses are illustrated in the following figures along with the speculations that can be made. Each figure from 1 to 8 corresponds to the questions that were asked.

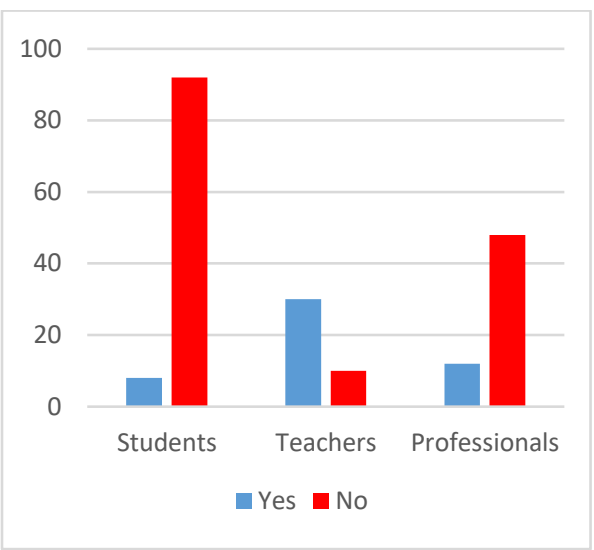

Figure 1: Awareness of Resources

Figure 1 illustrates the trend that almost all of the students and most of the professionals do not even check the available resources, although the teachers are mostly aware of the resources.

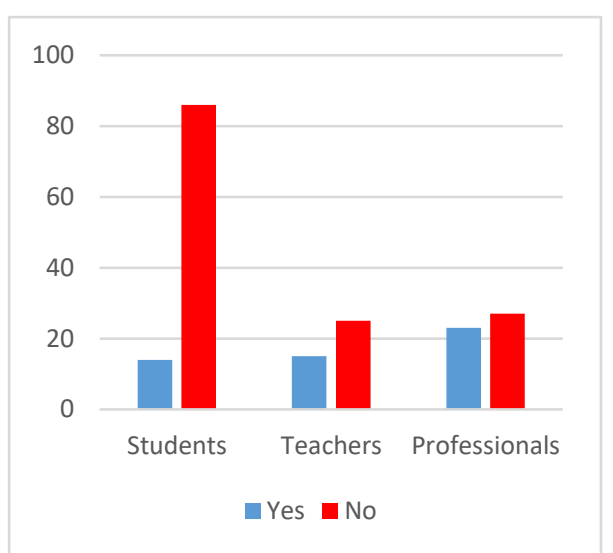

Figure 2: Optimization Practice

Figure 2 clearly indicates that most of the people do not try to optimize the solution. This problem is at its peak in case of students. Furthermore, the teachers and even the professionals do not practice the optimization of problems. 
Faryal Shamsi (et al.) Practical Implementation of academic course Analysis and Design of Algorithms taught in the

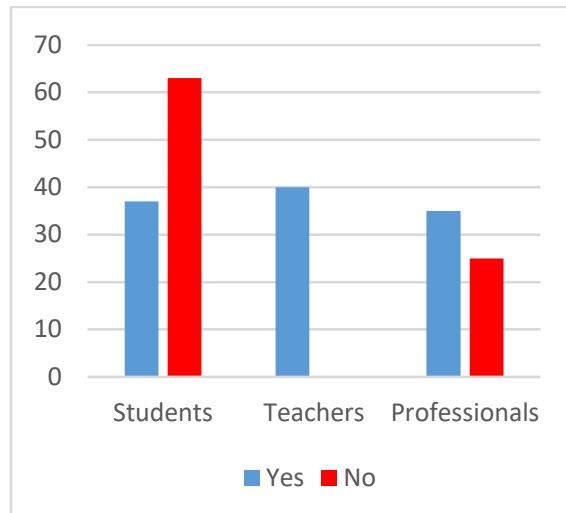

Figure 3 - Improved Decision Making

Figure 3 shows that all of the teachers expressed that the course has made a significant improvement in the decision making. Many professionals but a small proportion of students consider that the course has made impact on the decision making skills.

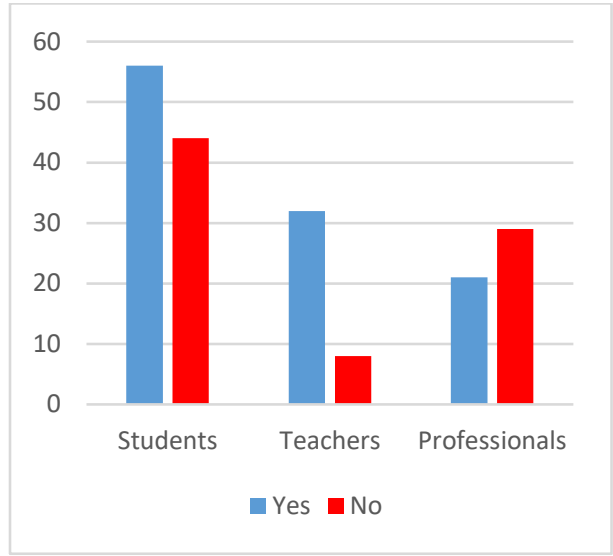

Figure 4 - Improved Problem Solving

Figure 4 surprisingly indicates that most of the professionals think that the course of analysis and design of algorithms has no major impact on their problemsolving skills. On the other hand, students and teacher were found to be optimistic about the impact of the course on their problem -solving skills.

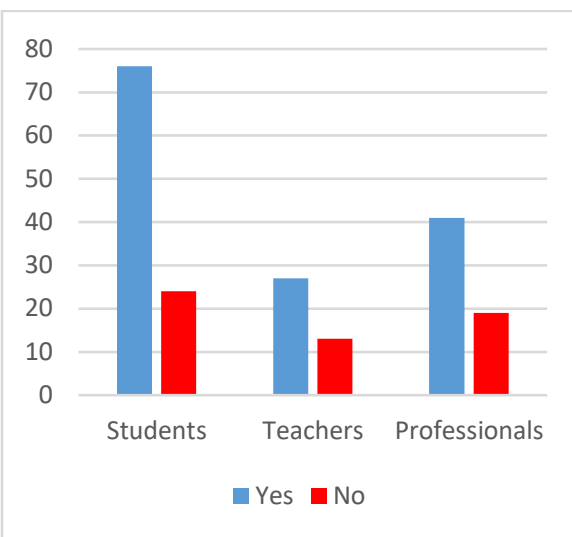

Figure 5 - Have interest in the course

Figure 5 reveals the fact that lack of interest is not actually the core issue here. The majority of students, teachers and professionals responded that they find the course interesting.

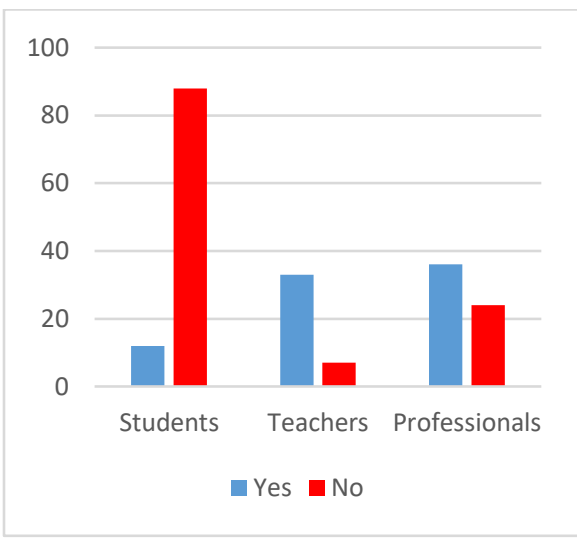

Figure 6 - Weakness in Mathematics

Figure 6 removes the misconception that weak mathematical foundation is the barrier in the practical implementation of the course. A large number of students reported to have strong mathematics. 


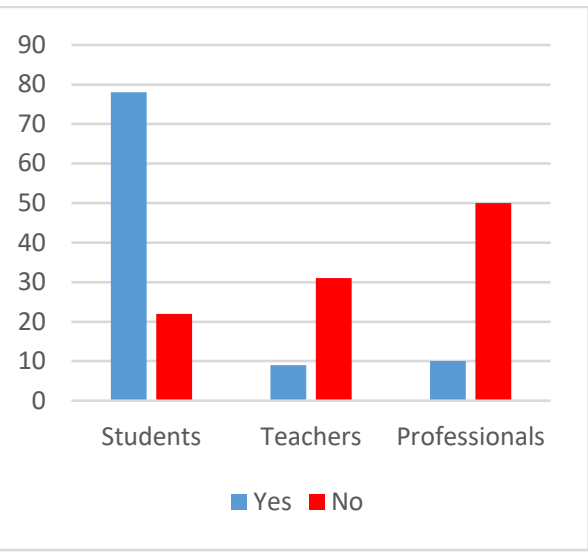

Figure 7 - Difficulty in relating mathematical expressions with real world problems

Figure 7 diagnoses the first major distraction and barrier for students in the way of practical implementation of the course concepts. This is the difficulty to relate the real world problems with the mathematical expressions.

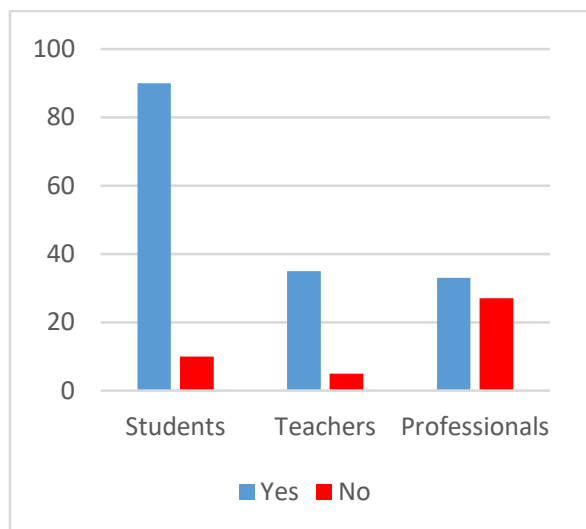

Figure 8 - Problematic Teaching Methodology

Figure 8 points out a major barrier towards the practical implementation of analysis and design of algorithms reported by all the respondents - Students, Teachers and Professionals. That's the Teaching Methodology.
For further investigation, the score of individual with respect to practical implementation was calculated. The correlation of each distraction with the practical implementation was calculated. The values for mathematical background, interest in the course, difficulty in relating with expressions and teaching methodology were found to be $-0.23,0.03$, 0.51 and -0.67 respectively.

The data clearly summarizes that the one major barrier in the practical implementation of the academic course of analysis and design of algorithms specifically in the Universities of Pakistan is the teaching methodology. Although the result suggest that, there is another barrier that is the difficulty in relating the mathematical statements to the real world analysis of algorithm issues. It can be assumed that the other barrier is also related to teaching methodology. It is the inappropriate teaching style that causes the students the stated problem. On the basis of this assumption it is necessary to investigate that if the teaching methodology a major barrier for all three populations (i.e. Students, Teachers and professionals. For that purpose the Chi-Square test to homogeneity was applied to the results of the three populations.

$\mathbf{H}_{0}$ : Teaching Methodology is not a barrier to Students, Teachers and Professionals

$\mathbf{H}_{\mathrm{A}}$ : Teaching Methodology is a barrier to Students, Teachers and Professionals

\begin{tabular}{|l|l|l|l|l|}
\hline \multirow{2}{*}{} & \multicolumn{3}{|c|}{$\begin{array}{c}\text { Satisfied with } \\
\text { Teaching Methodology }\end{array}$} & Total \\
\cline { 2 - 5 } & & YES & NO & \\
\cline { 2 - 5 } & & 90 & 10 & 100 \\
\cline { 2 - 5 } & Teachers & 35 & 5 & 40 \\
\hline
\end{tabular}


Faryal Shamsi (et al.) Practical Implementation of academic course Analysis and Design of Algorithms taught in the Universities Of Pakistan

\begin{tabular}{|r|r|l|l|l|}
\hline & Professionals & 33 & 27 & 60 \\
\cline { 2 - 5 } & Total & 158 & 42 & 200 \\
\hline
\end{tabular}

By using the above contingency table, the degree of freedom is 2 , and the estimated Chi-square value is 29.86793 which is significant. The p-value 5.991 is much lower than the Chi-square value, so we can reject the null hypothesis and accept the alternative. This proves that the teaching methodology being used in the universities of Pakistan is not suitable for the course of analysis and design of algorithms and requires some instantaneous reforms.

\section{Speculations}

- The results suggest that most of the people in the computer science community are not performing the analysis of algorithms.

- It is obvious that most of the people do not even check the resources. But even considering the people who claim to check the resources, does not suggest that they manage the resources effectively, or even try to manage at all.

- Limited number of people try to optimize the solution while the rest just fix the problem at any cost and forget it forever.

- All the teachers believe that the course has made a significant impact on their overall potential in terms of decision making and problem solving skills. The impact on other respondents was found to be insignificant.

- Lack of interest and poor mathematics is not the greatest barrier to analysis. Most of the respondents were found to have interest in the field as well as good mathematical skills but were not satisfied with the teaching methodology.

- The major barrier to analysis and design of algorithm was proved to be the teaching methodology. Even if the students are unable to relate the mathematical expressions with real world analytical problems, it reflects the problematic teaching methodology.

\section{Recommendations}

- The analysis and design of algorithms must be taught as an advanced course. Most students study it in the initial phase of the computer science education, while this course demands a great deal of prior knowledge. For Example -

- Major programing techniques and different languages.

- Major Mathematical Course -

- Calculus

- Discrete Mathematics

- Computational Maths

- Probability Statistics

- Inferential Statistics

- Data Structures

- Theory of Automata

- Traditional teaching methodology is a major distraction. There must be some innovative techniques to maintain students' interest and motivation.

- The significance and importance of analysis should be communicated effectively and convincingly to retain the motivation level of the students.

- Students must be provided with limited computational resources to encourage optimization.

- Benchmarks must be used in the classroom to evaluate the 
Faryal Shamsi (et al.) Practical Implementation of academic course Analysis and Design of Algorithms taught in the

performance of different computational solutions

- Simulators and graphical objects must be used connect the real world analytical problems with complicated mathematical expressions.

- $\quad$ As the programing and computational techniques have evolved from linear programing to visual programing and automated application development. The analysis techniques must also evolve by use of artificial intelligence, quantum computation or Data Mining etc.

\section{Conclusion}

The purpose of the course of Analysis and Design of Algorithms is to equip the computer science community with the abilities of problem solving, resource management, code optimization. Unfortunately, it is contemplated that the essence of the curriculum is not extracted by the computer science community.

After a thorough survey based study, it was scrutinized that course is studied compulsorily but applied rarely by the computer science community. The article proves the claim and pinpoints some barriers of analysis of algorithms. The recommendations in reforms required in the teaching methodology to overcome such barriers are also specified.

\section{ACKNOWLEDGMENT}

We are thankful to all the experts, professionals, our teachers and other teachers who supported us throughout the research and provided with their feedback and precious comments.

\section{REFERENCES}

[1] Thomas H. Cormen, Charles E. Leiserson, Ronald L. Rivest, Clifford Stein, "Introduction to Algorithms", Massachusetts Institute of Technology, Cambridge, London, England. (2009)

[2] https://en.wikipedia.org/wiki/Analysis of algor ithms, Wiki Encyclopedia
[3] Xuemin Zhang, Zenggang Xiong, Yaomin Ding, Guangwei Wang, Conghuan Ye, "Research-oriented teaching of Design and Analysis of Algorithm", esearch-oriented teaching of Design and Analysis of Algorithm (2012)

[4] HEC Course Schema. Course Outline for Analysis and Design of Algorithm 2013,

http://hec.gov.pk/english/services/universities/R evisedCurricula/Documents/20122013/computer-science\%202012-13.pdf

Sukkur IBA Journal of Computing and Mathematical Sciences - SJCMS | Volume 1 No. 2 July - December 2017 (C) Sukkur IBA University 